\title{
DNA barcoding and phylogenetic analyses of the genus Coleosporium (Pucciniales) reveal that the North American goldenrod rust $C$. solidaginis is a neomycete on introduced and native Solidago species in Europe
}

\author{
Ludwig Beenken $^{1} \cdot$ Matthias Lutz ${ }^{2}$ Markus Scholler ${ }^{3}$
}

Received: 20 September 2017 / Accepted: 27 October 2017 / Published online: 10 November 2017

(C) German Mycological Society and Springer-Verlag GmbH Germany, part of Springer Nature 2017

\begin{abstract}
Recently, an unknown rust fungus of the genus Coleosporium appeared in Germany and Switzerland on giant goldenrod, Solidago gigantea, an invasive neophyte from North America, and on the indigenous European goldenrod, S. virgaurea. For identification, DNA barcodes were assembled in the course of the German Barcode of Life (GBOL) project and the investigation of neomycetes in Switzerland. Phylogenetic analyses were performed using ITS and LSU sequences of Coleosporium species representing various host plants and geographic regions. These analyses resulted in the first molecular evidence of the North American rust Coleosporium solidaginis in Europe. Coleosporium solidaginis is split into two subclades that are closely related to Coleosporium asterum, a species on Aster s.1., which was formerly synonymized with $C$. solidaginis. The genus is
\end{abstract}

Section Editor: Franz Oberwinkler

Electronic supplementary material The online version of this article (https://doi.org/10.1007/s11557-017-1357-2) contains supplementary material, which is available to authorized users.

Ludwig Beenken

ludwig.beenken@wsl.ch

Matthias Lutz

matthias.lutz@uni-tuebingen.de

Markus Scholler

markus.scholler@smnk.de

1 Swiss Federal Research Institute WSL, 8903 Birmensdorf, Switzerland

2 Plant Evolutionary Ecology, Institute of Evolution and Ecology, University of Tübingen, Auf der Morgenstelle 5,

72076 Tübingen, Germany

3 Staatliches Museum für Naturkunde Karlsruhe, Erbprinzenstr. 13, 76133 Karlsruhe, Germany divided into an American and a Eurasian clade. This phylogenetic pattern indicates that the geographic distribution, rather than the relationship with host plants, played a major role in the evolution of Coleosporium species. This finding particularly applies to the European species, which are genetically uniform according to the ITS and LSU sequences. Taxonomical consequences are discussed. Coleosporium solidaginis is fragmentarily distributed in Europe. The place of its introduction and host shift to $S$. virgaurea remains uncertain. Life cycle and propagation are mainly restricted to asexual urediniospores. Telia were found only once and the aecial stage was not observed at all on pine trees. The ecological impact of this neomycete is still unknown, but C. solidaginis has the potential to harm wild and cultivated goldenrods in Europe.

Keywords Coleosporium asterum · GBOL · Host shift · Solidago canadensis $\cdot$ Solidago gigantea $\cdot$ Solidago virgaurea

\section{Introduction}

Neobiota, alien organisms, can have a large impact on the indigenous flora and fauna of the area where they have been introduced (e.g., Kowarik and Rabitsch 2010). In particular, plant parasitic neomycetes ${ }^{1}$ can cause severe damage to forest trees and agricultural plants (e.g., Large 2003; Santini et al. 2013; Sieber 2014). Whereas these economically important alien fungi have been investigated thoroughly, current knowledge on other neomycetes and their influence on wild plants in

\footnotetext{
${ }^{1}$ Neomycetes were originally defined as introduced alien fungi that had established in a new area after 1492 (Kreisel and Scholler 1994). Other authors (e.g., Beenken and Senn-Irlet 2016; Klenke and Scholler 2015) have used the term in a broader sense, including also non-established ephemeral fungi.
} 
natural ecosystems is insufficient (e.g., Beenken and SennIrlet 2016).

Rust fungi (Pucciniales) are an important group of plant parasitic fungi containing many neomycetes: 33 alien rust fungus species have been observed in Switzerland (Beenken and Senn-Irlet 2016) and around 40 have been found in Germany (Scholler, unpublished data). Most of these neomycete rust fungi occur only on their original host plants, which were also introduced to the area, as in the cases of Phragmidium mexicanum (Mains) H.Y. Yun, Minnis \& Aime on Potentilla indica (Andrews) Th. Wolf [= Frommeëlla mexicana (Mains) J.W. McCain \& J.F. Hennen on Duchesnea indica (Andrews) Focke] and Puccinia komarovii Tranzschel ex P. Syd. \& Syd. on Impatiens parviflora DC. Several introduced rusts are known to occur almost exclusively on native plants; for example, Melampsoridium hiratsukanum S. Ito ex Hirats. has two indigenous major telial hosts in Europe, Alnus incana (L.) Moench and A. glutinosa (L.) Gaertn. (Hantula and Scholler 2013). Others infect introduced as well as indigenous plants, e.g., Puccinia malvacearum Bertol. ex Mont. occurs on several species of Malvaceae (Beenken and Senn-Irlet 2016; Klenke and Scholler 2015).

A Coleosporium species appeared on the introduced goldenrod, Solidago gigantea Ait. (Asteraceae), as well as on the indigenous S. virgaurea L. in southwest Germany in 2009 (Klenke and Scholler 2015) and in Switzerland in 2012 (Beenken and Senn-Irlet 2016; Brodtbeck 2017). There are numerous native Coleosporium species known to occur on several Asteraceae spp. in Europe, but none of these species had previously been found on Solidago spp. in this region (e.g., Gäumann 1959; Helfer 2013). Therefore, Klenke and Scholler (2015), who first reported occurrences of this Solidago rust in Central Europe, provisionally named it Coleosporium asterum (Dietel) Syd. \& P. Syd., a species occurring on Solidago spp. in North America and Asia (e.g., Arthur 1962; Farr and Rossman 2017; Ginns 1986). Later, Beenken and Senn-Irlet (2016) and Brodtbeck (2017) reported further occurrences in Switzerland. In northern Spain, it was already found on S. virgaurea in 2007 (Menéndez and Rubio 2012).

\section{The host plants}

The genus Solidago (Asteraceae) includes ca. 100 species in North and Central America, Eurasia, and northernmost Africa (Wagenitz 1979). With more than 75 species occurring in North America, this region is the biodiversity hotspot of the genus (Flora of North America in http://www.efloras.org). In Europe and North Africa, only $S$. virgaurea is native; this species is also distributed throughout temperate Asia and is split into several subspecies (Wagenitz 1979). Solidago virgaurea is a medicinal plant used in urinary tract diseases and is, therefore, cultivated in Germany and Switzerland (Kołodziej 2009; Schenk and Lück 2012; Vogel 2017). Solidago gigantea, like $S$. canadensis L., is native to North America. Both species have been introduced in many regions of the world, including Europe (Kowarik and Rabitsch 2010; Wagenitz 1979; Weber and Jakobs 2005). Solidago gigantea was introduced in England in 1758 as an ornamental plant and later on the European continent, where it soon grew wild. Since the mid-twentieth century, the species has become invasive in Central Europe (Kowarik and Rabitsch 2010; Weber and Jakobs 2005). Therefore, S. gigantea and S. canadensis are both on the "black list" of invasive neophytes in Switzerland (Weber 2013, https://www.infoflora.ch) and Germany (Nehring et al. 2013).

\section{The genus Coleosporium}

The pine needle rust genus Coleosporium (Coleosporaceae, Pucciniales) contains more than 100 species, which are mainly distributed in the temperate northern hemisphere but occur also in tropical regions (Farr and Rossman 2017; Kirk et al. 2008). Additionally, there have been multiple Coleosporium species introductions, e.g., in South America (Hennen et al. 2005), South Africa (Van Reenen 1995), Australia (Shivas et al. 2017), and New Zealand (McKenzie 1998), where host-alternating species often survive without an aecial host. Most species are heteroecious, with spermogonia and aecia on needles of Pinus spp. and uredinia and telia mainly on leaves of several dicot taxa (e.g., Helfer 2013; Kaneko 1981). In Europe, their native telial hosts belong to the families Asteraceae, Campanulaceae, Orobanchaceae, and Ranunculaceae (Gäumann 1959; Helfer 2013; Klenke and Scholler 2015). Outside Europe, Coleosporium species occur also on several other host plant families (Farr and Rossman 2017), such as Apocynaceae, Convolvulaceae, Lamiaceae, and Rutaceae (Table S1).

Depending on the authors and their species concept, one Coleosporium species with several formae speciales (Helfer 2013), 14 species (Gäumann 1959), or up to 20 species (Klenke and Scholler 2015) have been reported to exist in Europe. Coleosporium species are difficult to distinguish morphologically and, thus, are defined mainly by telial host taxonomy. Generally, one fungal species has been restricted to the plant species of a single genus or family (e.g., Gäumann 1959). Klebahn (1914) and Gäumann (1959), however, reported that several European Coleosporium species, mainly on Asteraceae, infect exotic plants of different families, namely Schizanthus grahami Gill. ex Hooker (Solanaceae) and Tropaeolum spp. (Tropaeolaceae). Thus, species identification of Coleosporium specimens on Solidago spp. has been challenging and the question has arisen as to whether it is really a neomycete or whether it is an indigenous Coleosporium species that jumped to Solidago spp. from non-related hosts. This 
phenomenon happens quite frequently with plant parasitic fungi and has most recently been reported for powdery mildews in Switzerland (Beenken 2017).

The aim of this study was to identify the Coleosporium specimens on goldenrod species in Germany and Switzerland by molecular phylogenetic analyses and to resolve their relationships to other European, Asian, and American species on several host species.

\section{Materials and methods}

\section{Fungal collections}

To form a dataset that was as complete as possible for the phylogeny of the genus, samples of almost all host plant species infected by Coleosporium spp. in Europe were collected during numerous field trips in Germany (particularly SW Germany) and Switzerland or taken from herbarium specimens (Tables S1 and S2). German material was obtained in the course of the German Barcode of Life (GBOL) project. To find additional specimens of goldenrod rust in Switzerland, sites where alien and native Solidago spp. occur (according to https://obs.infoflora.ch/app/neophytes/de/index.html) were selected, and the plants at these sites were systematically checked for Coleosporium infections (Table S3; Beenken and Senn-Irlet 2016). From each location, one collected specimen of infected $S$. gigantea and/or of infected S. virgaurea was chosen for molecular analyses (Tables S1 and S2). The rust identification was confirmed by light microscopy, and each specimen was assigned to a species following the biological species concept of Gäumann (1959) and Klenke and Scholler (2015). Voucher specimens were deposited in KR and ZT (Tables S1 and S2).

\section{Molecular analyses}

Total DNA was extracted from small pieces of leaves (ca. $3 \times 3 \mathrm{~mm}$ ) with fungal infections, which were dried on silica gel, using the NucleoSpin Plant II extraction kit (MachereyNagel, Düren, Germany), following the manufacturer's standard protocol for plant tissue. The ITS1-5.8S-ITS2 and the neighboring part of the LSU region of the nrDNA were PCRamplified and sequenced following the protocol described by Beenken et al. (2012) using the rust fungi-specific primer pairs ITS5u/ITS4rust and LRust1R/LR6 (Beenken et al. 2012; Pfunder et al. 2001; Vilgalys and Hester 1990). Sequences were deposited in GenBank (accession numbers are given in Table S1). The sequences of the rust fungi were compared with accessions deposited in GenBank by applying the Basic Local Alignment Search Tool (BLAST) using the nucleotide search option (blastn) (Altschul et al. 1990). The phylogenetic position of the collected Solidago rusts within the genus
Coleosporium was analyzed. For this purpose, sequences were combined with sequences of Coleosporium spp. from the GBOL project (http://www.bolgermany.de; Geiger et al. 2016). All Coleosporium spp. sequences available from GenBank, for which host plants and geographic origin were indicated, were included in the analyses. Thus, the datasets contained Coleosporium spp. occurring on different host plants and originating from different parts of the world (Table S1). Separate ITS and LSU alignments were created because neither the LSU nor the ITS were available for all species (Table S1). All alignments were performed using MAFFT v.7.017 (Katoh et al. 2002; Katoh and Standley 2013). Ambiguous regions within the resulting alignments were excluded from analyses with Gblocks v.0.91b (Castresana 2000).

The LSU alignment of $549 \mathrm{bp}$ in length contained 58 sequences of Coleosporium spp., one sequence of a Uredo sp., and one of Chrysomyxa rhododendri (DC.) de Bary, the sister genus of Coleosporium (Maier et al. 2003). The closely related Cronartium ribicola J. C. Fisch (Maier et al. 2003) was used as the outgroup in the LSU analysis. The alignment of the ITS1-5.8S-ITS2 region (637 bp) included 71 sequences of Coleosporium spp. (Table S1), and the sequence of Chrysomyxa rhododendri was used as the outgroup (following the LSU analysis; Fig. 1). The eight sequences lacking the ITS1 region taken from GenBank (Table S1) were supplemented with unknown bases $(\mathrm{N})$ in the ITS alignment. To validate this approach, the same ITS dataset but containing only the 5.8S-ITS2 region (270 bp) was used. Additionally, a combined alignment was created using 26 ITS1-5.8SITS2-LSU sequences and five 5.8S-ITS2-LSU sequences, with a total length of $1254 \mathrm{bp}$.

The datasets were analyzed using the maximum likelihood (ML) methods implemented in RAxML v.7.2.8 (Stamatakis 2006). Analyses were performed assuming a general timereversible (GTR) model of nucleotide substitution and estimating a discrete gamma distribution (GTRGAMMA option in RAxML) with partitions according to the submatrices, which allowed multiple models of substitution. One thousand runs with distinct starting trees were completed using the rapid bootstrap (BS) algorithm of RAxML (Stamatakis et al. 2008). The resulting phylogenetic ML trees were rooted and visualized using the Dendroscope program (Huson et al. 2007).

\section{Results}

\section{BLAST search}

The ITS1-5.8S-ITS2 sequences of all Coleosporium samples found on S. gigantea and S. virgaurea in Germany and Switzerland were identical. The same result was found for the investigated LSU sequences. The 5.8S-ITS2 sequence of 
LSU

Host families:

Apocynaceae

Astereaceae

Campanulaceae

Convulvolaceae

Lamiaceae

Orobanchaceae

Rutaceae

Coleosporium solidaginis (GU058009) on Solidago sp. USA

Coleosporium solidaginis (AB847106) on Solidago virgaurea var. gigantea South Korea

Coleosporium solidaginis LB10683 on Solidago gigantea Switzerland ZH

Coleosporium solidaginis KR-M-0037189 on Solidago gigantea Germany

Coleosporium solidaginis LB10673 on Solidago virgaurea Switzerland ZH

Coleosporium solidaginis LB10586 on Solidago virgaurea Switzerland TI

Coleosporium solidaginis (DQ354559 on Solidago sp. USA

C. solidaginis I

Coleosporium solidaginis LB10658 on Solidago virgaurea Switzerland ZH

Coleosporium solidaginis (HQ317530) on Solidago sp. Canada

Coleosporium solidaginis LB09929 on Solidago virgaurea Switzerland TI

97 Coleosporium solidaginis LB10585 on Solidago gigantea Switzerland TI

52 Coleosporium solidaginis (AB847107) on Solidago virgaurea var. gigantea South Korea Coleosporium solidaginis (KX669028) on Solidago canadensis China

${ }_{95}$ Coleosporium solidaginis (KX669028) on Solidago canadensis China - C. solidaginis II

America

Coleosporium asterum (JF273969) on Symphyotrichum pilosum South Korea

Coleosporium asterum (KX420703) on Aster spathulifolius South Korea

Coleosporium asterum (JF273970) on Symphyotrichum pilosum South Korea

C. asterum

Coleosporium asterum (JF273968) on Symphyotrichum pilosum South Korea

Coleosporium asterum (AF426241) on Symphyotrichum ciliolatum Canada

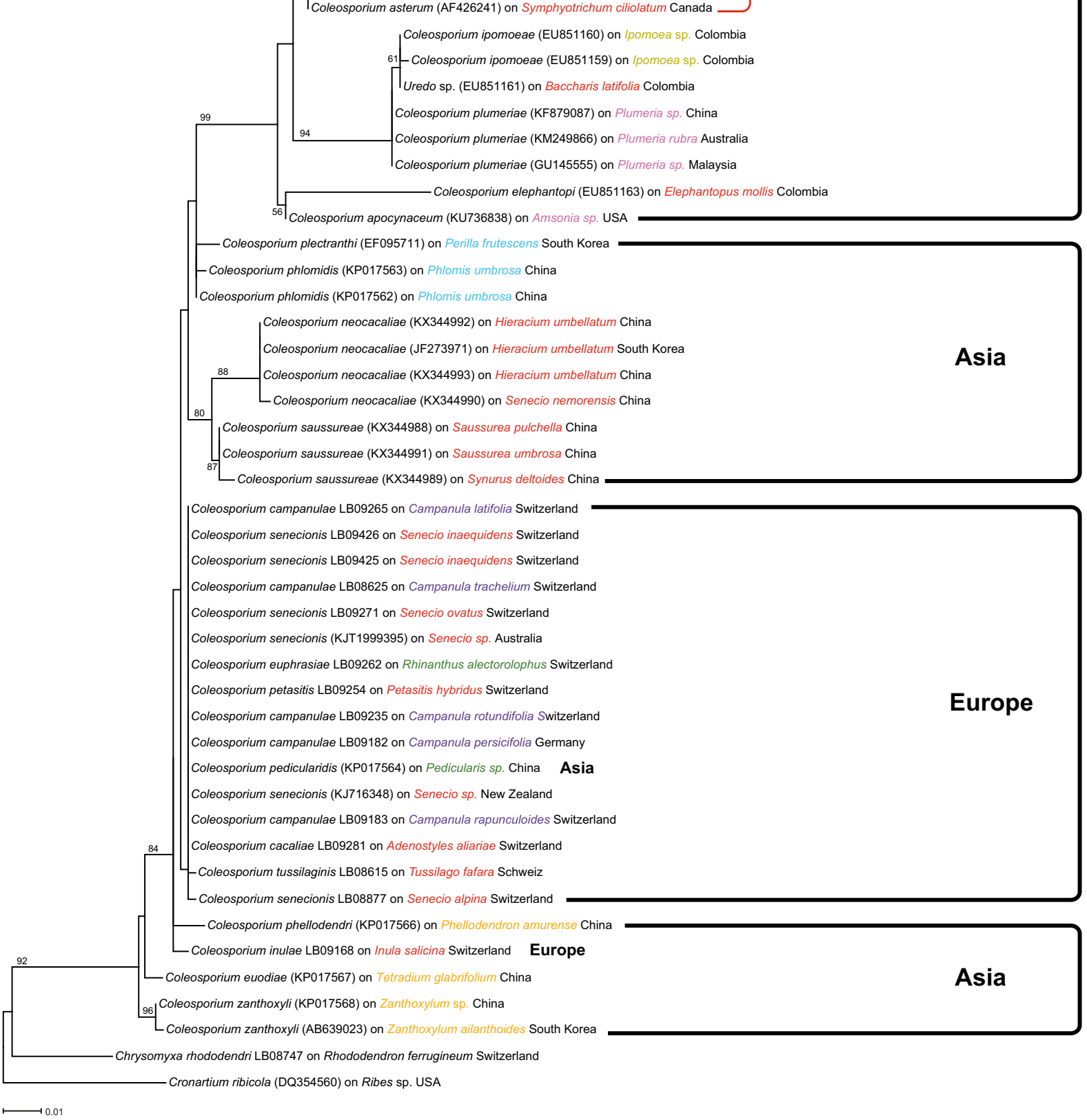


Fig. 1 Phylogenetic positions of Coleosporium solidaginis and C. asterum within the genus Coleosporium, based on maximum likelihood (ML) analysis with RAxML v.7.2.6 recovered from LSU sequence data. The numbers at nodes indicate RAxML bootstrap support $>50 \%$. Samples are given with species name, GenBank accession number (in parentheses) or voucher number, host plant, and origin (see also Table S1). Families of host plants are coded by color (see insert)

the European Solidago rust was nearly identical (> 99\%) and the LSU sequence was $100 \%$ identical to the corresponding sequences of Coleosporium solidaginis $(=C$. asterum $)$ on Solidago spp. from North America in GenBank (accession numbers: DQ354559, GU58009, and HQ317530).

\section{Phylogenies}

Figure 1 shows the tree resulting from the RAxML analysis of the LSU sequences, Fig. 2 of the ITS1-5.8S-ITS2 sequences, Fig. S1 of the 5.8S-ITS2 sequences, and Fig. S2 of the ITS15.8S-ITS2-LSU sequences. There were no mismatches between the topologies of these trees but the bootstrap supports of the clades were higher in the ITS1-5.8S-ITS2 analysis than in the other ITS analyses. In all phylogenetic analyses, the Coleosporium samples on Solidago spp. from Europe formed, together with the samples of Coleosporium spp. on Solidago spp. from North America and Asia, a single well-supported clade (C. solidaginis I clade in Figs. 1 and 2) that was well separated from the indigenous European Coleosporium species (Figs. 1, 2, S1, and S2). Two Coleosporium collections on $S$. canadensis from China appeared in a sister position to the clade in the LSU tree (C. solidaginis II clade in Fig. 1). The C. asterum samples on Aster spathulifolius Maxim., Symphyotrichum pilosum (Willd.) G.L. Nesom from South Korea, and on $S$. ciliolatum (Lindley) Á. Löve \& D. Löve from Canada in the LSU analysis (Fig. 1, C. asterum clade), as well as the Coleosporium sample on Eurybia macrophylla (L.) Cass. (= Aster macrophyllus L.) from Canada in the ITS analyses (Figs. 2 and S1), appeared to be separated from the rusts on Solidago spp. All these Coleosporium samples formed, together with all other species of American origin [C. apocynaceum Cooke, C. elephantopodis Thüm., C. ipomoeae (Schwein.) Burrill, C. plumeriae Pat., and Uredo sp. on Baccharis sp.], a well-supported clade (Fig. 1). The European and Asian species appeared in the basal position to the clade of American species (Fig. 1).

With the exception of $C$. inulae Rabenh., all European Coleosporium species revealed more or less identical LSU sequences and appeared in one clade in the LSU tree (Fig. 1). In the ITS trees (Figs. 2 and S1), C. inulae was also well separated from all other European species that were monophyletic, with $C$. pulsatillae (F. Strauss) Fuckel and C. pedicularis F.L. Tai (from China) in the basal position to the remaining European species. The ITS region did not resolve the
European Coleosporium rusts occurring on Orobanchaceae [C. euphrasiae (Schumach.) G. Winter on the genera Euphrasia, Odontites, and Rhinanthus; C. melampyri (Rebent.) Kleb. on Melampyrum spp.], on Campanulaceae [C. campanulae (Pers.) Lév. on Campanula spp.], and on a part of Asteraceae [C. cacaliae G.H. Otth. on Adenostyles alliariae (Gouan) A. Kern., C. senecionis (Pers.) Fr. on native Senecio spp., as well as the introduced $S$. inaequidens, C. sonchi Lév. on Sonchus spp.]. Coleosporium tussilaginis (Pers.) Berk. on Tussilago farfara L. (Asteraceae) and C. petasitis Cooke on Petasites hybridus (L.) G. Gaertn., B. Mey. \& Scherb. (Asteraceae) appeared together on a wellsupported subclade nested within these European Coleosporium clades (Fig. 2) or in sister position to them (Fig. S2). The Asian species occurring on Asteraceae (C. neocacaliae Saho and C. saussureae Thüm.), on Lamiaceae (C. plectranthi Barclay and C. phlomidis Z.M. Cao \& Z.Qi Li), on Orobanchaceae (C. pedicularis), on Ranunculaceae (C. cimicifugatum Thüm.), and on Rutaceae (C. euodiae Dietel, C. phellodendri Kom., and C. zanthoxyli Dietel \& P. Syd.) were well separated from each other. They did not appear in a single clade but were intermixed with the European species (Figs. 1, 2, S1, and S2).

\section{Discussion}

\section{Nomenclature and taxonomy}

There is some confusion concerning the use of the two species names $C$. asterum and $C$. solidaginis. Therefore, the correct name of the goldenrod rust needs to be clarified before discussing our results in detail. Moreover, recent changes in nomenclatural rules (McNeill et al. 2012) and our phylogenetic results necessitate nomenclatural and taxonomical rearrangements.

In 1822, Schweinitz (see also Arthur and Bisby 1918) described Uredo solidaginis Schwein. on Aster, Solidago, and Vernonia species from North Carolina, USA. Thümen (1878) changed the name to Coleosporium solidaginis (Schwein.) Thüm. and listed Solidago puberula Nutt. and S. gigantea as hosts from the east coast of the USA. Later, Dietel (1900) described Stichopsora, a genus from Japan that is closely related to Coleosporium and consists of one species, Stichopsora asterum Dietel. As host plants, he listed Callistephus chinensis (L.) Nees, Doellingeria scabra (Thunb.) Nees (as Aster scaber Thunb.), Aster tataricus L.f., and Kalimeris indica (L.) Sch.Bip. (as A. indicus L.). Sydow and Sydow (1914) synonymized the genera by naming the species Coleosporium asterum (Dietel) Syd. \& P. Syd. Finally, Cummins (1962) listed C. solidaginis as a synonym of $C$. asterum because $C$. solidaginis has been described only from uredinia. This approach was correct according to the 
ITS1-5.8S-ITS2

Host families:

Apocynaceae

Astereaceae

Campanulaceae

Convulvolaceae

Lamiaceae

Orobanchaceae

Ranunculaceae

Rutaceae

Coleosporium euphrasiae KR-M-0003924 Rhinanthus alectorolophus Germany

Coleosporium euphrasiae LB09262 on Rhinanthus alectorolophus Switzerland

Coleosporium euphrasiae KR-M-0029704 Rhinanthus alectorolophus Germany

Coleosporium melampyri KR-M-0002704 on Melampyrum pratense Germany

Coleosporium melampyri KR-M-0025239 on Melampyrum pratense Germany

Coleosporium euphrasiae KR-M-0025167 Rhinanthus glacialis Germany

Coleosporium campanulae LB08625 on Campanula trachelium Switzerland

Coleosporium melampyri KR-M-0025242 on Melampyrum pratense Germany

Coleosporium campanulae KR-M-0033870 on Campanula rapunculoides Germany

Coleosporium campanulae LB09235 on Campanula rotundifolia Switzerland

Coleosporium campanulae KR-M-0025361 on Campanula rotundifolia Germany

Coleosporium senecionis KR-M-0035397 on Senecio inaequidens Germany

Coleosporium euphrasiae KR-M-0003118 Euphrasia officinalis Germany

Coleosporium melampyri KR-M-0022652 on Melampyrum sylvaticum Germany

Coleosporium cacaliae LB09281 on Adenostyles aliariae Switzerland

Coleosporium senecionis LB08877 on Senecio alpina Switzerland

Coleosporium senecionis KR-M-0033476 on Senecio ovatus Germany

Coleosporium senecionis KR-M-0025321 on Senecio ovatus Germany

Coleosporium senecionis KR-M-0016335 on Senecio nemorensis Germany

Coleosporium senecionis LB09271 on Senecio ovatus Switzerland

Coleosporium euphrasiae KR-M-0025304 Odontites vulgaris Germany

Coleosporium sonchi KR-M-0033355 on Sonchus arvensis Germany

Coleosporium sonchi KR-M-0033479 on Sonchus asper Germany

Coleosporium campanulae (KP017555) on Campanula sp. China Asia

Coleosporium campanulae LB09265 on Campanula latifolia Switzerland

Coleosporium campanulae LB09182 on Campanula persicifolia Germany

Coleosporium campanulae KR-M-0017552 on Campanula trachelium Germany

Coleosporium campanulae LB09305 on Campanula cochliarifolia Switzerland

Coleosporium melampyri KR-M-0033483 on Melampyrum pratense Germany

Coleosporium campanulae LB09183 on Campanula rapunculoides Switzerland

Coleosporium melampyri KR-M-0033411 on Melampyrum pratense Germany

Coleosporium senecionis KR-M-0018930 on Senecio inaequidens Germany

Coleosporium senecionis LB09425 on Senecio inaequidens Switzerland

Coleosporium senecionis LB09426 on Senecio inaequidens Switzerland

Coleosporium senecionis (KJ716348) on Senecio sp. New Zealand

Coleosporium petasitis LB09254 on Petasitis hybridus Switzerland

$1{ }^{64}$ Coleosporium petasitis KR-M-0012221 on Petasitis hybridus Germany

Coleosporium tussilaginis LB08615 on Tussilago fafara Schweiz

Coleosporium tussilaginis KR-M-0016008 on Tussilago fafara Germany

$76 \quad 100$ Coleosporium pulsatillae KR-M-0021308 on Pulsatilla vulgaris Germany

Coleosporium pulsatillae KR-M-0014421 on Pulsatilla vulgaris Germany

Coleosporium pedicularidis (KP017554) on Pedicularis sp. China

$100 \quad$ Coleosporium phellodendri (KX225406) on Phellodendron amurense China

Coleosporium phellodendri (KP017556) on Phellodendron amurense China

Asia

$100 \quad$ Coleosporium cimicifugatum (KP017558) on Cimicifuga sp. China

Coleosporium cimicifugatum (KP017559) on Cimicifuga sp. China

Coleosporium solidaginis LB10683 on Solidago gigantea Switzerland ZH Coleosporium solidaginis LB10673 on Solidago virgaurea Switzerland ZH Coleosporium solidaginis KR-M-0037189 on Solidago gigantea Germany Coleosporium solidaginis LB09929 on Solidago virgaurea Switzerland TI Coleosporium solidaginis LB10586 on Solidago virgaurea Switzerland TI Coleosporium solidaginis LB09842 on Solidago virgaurea Switzerland ZH Coleosporium solidaginis LB10585 on Solidago gigantea Switzerland TI Coleosporium solidaginis LB11178 on Solidago gigantea Switzerland ZH Coleosporium solidaginis LB10594 on Solidago gigantea Switzerland TI - Coleosporium solidaginis (GU058009) on Solidago sp. USA Coleosporium solidaginis LB10658 on Solidago virgaurea Switzerland ZH ${ }_{100} \quad \underbrace{}_{\text {Coleosporium plumeriae (KF879087) on Plumeria sp. China }} \begin{aligned} & \text { Coleosporium solidaginis (HQ317530) on Solidago sp. Canada } \\ & \text { Coleosporium solidaginis (DQ354559 on Solidago sp. USA }\end{aligned}$ \begin{tabular}{l|l}
${ }_{100}$ & {$\left[\begin{array}{l}\text { Coleosporium solidaginis (HQ317530) on Solidago sp. Cana } \\
\text { Coleosporium solidaginis (DQ354559 on Solidago sp. USA }\end{array}\right.$} \\
Coleosporium plumeriae (KF879087) on Plumeria sp. China
\end{tabular} Coleosporium asterum (HQ317518) on Eurybia macrophylla Canada - C. asterum

Coleosporium inulae KR-M-24937 on Pinus sylvestris Germany

Coleosporium inulae LB09168 on Inula salicina Switzerland

Coleosporium inulae KR-M-24891 on Inula hirta Germany

Coleosporium inulae KR-M-24937 on Inula salicina Germany

100 Coleosporium phlomidis (KP017553) on Phlomis umbrosa China

Coleosporium phlomidis (KP017552) on Phlomis umbrosa China

Coleosporium euodiae (KP017557) on Tetradium glabrifolium China

Coleosporium zanthoxyli (KP017561) on Zanthoxylum sp. China

Coleosporium zanthoxyli (JQ219672) on Zanthoxylum sp. China

Coleosporium zanthoxyli (KP017560) on Zanthoxylum sp. Chin

Chrysomyxa rhododendri LB08747 on Rhododendron ferrugineum Switzerland 
4 Fig. 2 Phylogenetic positions of Coleosporium solidaginis and C. asterum within the genus Coleosporium, based on $\mathrm{ML}$ analysis with RAxML v.7.2.6 recovered from ITS1-5.8S-ITS2 sequence data. The numbers at nodes indicate RAxML bootstrap support $>50 \%$. Samples are given with species name, GenBank accession number (in parentheses) or voucher number, host plant, and origin (see also Table S1). Families of host plants are coded by color (see insert)

previous code of nomenclature (cf. McNeill et al. 2006). Consequently, authors (e.g., Klenke and Scholler 2015; Thite et al. 2016; Wang et al. 2017; Zhuang 1983, 2001; Index Fungorum 2017) called the Coleosporium rust on Solidago spp. C. asterum. According to the International Code of Nomenclature for algae, fungi and plants that has been in effect since 2011 (Melbourne Code, Article 59), the names of anamorphs and teleomorphs are to be "treated equally for the purposes of establishing priority, regardless of the life history stage of the type" (McNeill et al. 2012). Uredo solidaginis is the oldest valid description of the fungus and, consequently, the name Coleosporium solidaginis has priority. Additionally, our phylogenic analyses show that C. solidaginis and C. asterum are not conspecific (see discussion below).

Consequently, the naming of the Coleosporium species on Solidago species is:

Coleosporium solidaginis (Schwein.) Thüm., Bull. Torrey Bot. Club 6: 216 (1878).

$\equiv$ Uredo solidaginis Schwein., Schr. naturf. Ges. Leipzig 1: 70 (1822) (basionym).

三Stichopsora solidaginis (Schwein.) Dietel, Hedwigia 42: 181 (1903)

= Coleosporium asterum s. auct., non (Dietel) Syd. \& P. Syd., Ann. mycologici 12 (2): 109 (1914)

= Peridermium acicola Underw. \& Earle, Bull. Torrey Bot. Club 23 (10): 400 (1896).

Coleosporium pini-asteris Orish. is a further species occurring on Aster and Callistephus species in Asia, but not on Solidago spp. (Kaneko 1981). Coleosporium delicatulum (Arthur \& F. Kern) Hedgc. \& Long is known from species of Euthamia, a genus closely related to Solidago, but it differs in the ornamentation of its urediniospores (Arthur 1962; Cummins 1978).

\section{Phylogeny: biogeography versus host ranges}

Our phylogenetic analyses of LSU data show that the Solidago rusts are split into two subclades (Fig. 1). Two Coleosporium samples from China occurring on the American S. canadensis, which is an invasive neophyte in China (Wang et al. 2017), form the sister group of the samples

\footnotetext{
${ }^{2}$ The S. canadensis record from SW Germany by Klenke and Scholler (2015) was revised by one of the authors of the present study (M.S.) and was determined as $S$. gigantea.
}

on S. gigantea, S. virgaurea, and an unidentified Solidago species. In this context, it is conspicuous that, in one location, in the Blenio Valley, Ticino, Switzerland (Tables S2 and S3), $S$. virgaurea and $S$. gigantea were always infected, whereas the $S$. canadensis plants growing in close proximity to them were not. Also, in the remaining investigation areas, Coleosporium infection was not observed on S. canadensis prior to this study ${ }^{2}$ (Brodtbeck 2017; Table S3). This observation was surprising because the two introduced Solidago species are closely related and hybrids between them and hybrids of both species with S. virgaurea exist (Gudžinskas and Žalneravičius 2016; Pliszko and Zalewska-Gałosz 2016; Wagenitz 1979). Heath (1992) similarly described the host specificity of a Coleosporium strain obtained from $S$. canadensis based on infection experiments. Thus, it could be concluded that more than one Coleosporium species occurs on Solidago species.

The Solidago rusts are different from the $C$. asterum specimens on Aster s.l. species from Canada and South Korea (Figs. 1, 2, and S1). These results from molecular data support infection experiments conducted by Hedgcock and Hunt (1922). Also, Kaneko (1981) was not able to infect Solidago virgaurea var. asiatica Nakai with spores of $C$. asterum from Aster spp. and vice versa. Additionally, he described differences in telial and basidiospore morphology (Kaneko 1981). Dietel (1900) described C. asterum s. str. occurring on Aster s.l. from Japan, but $C$. asterum was also found on Aster s.l. in North America (Arthur 1962; Cummins 1978; Ginns 1986). Consequently, it remains unknown whether the American populations are conspecific with the Asian taxon. Five of six $C$. asterum samples used in our phylogenetic analyses were collected on Eurybia macrophylla (= Aster macrophyllus) and on Symphyotrichum ciliolatum ( $=$ A. ciliolatus) from Canada, as well as on S. pilosum (= A. pilosus), a species that was introduced from North America to South Korea (Table S1). Thus, they probably belong to the American $C$. asterum group. Sequencing Asian material - preferably from the type host of C. asterum, Aster tataricus (designated by Cummins 1978) - would be needed to barcode $C$. asterum s.str. This would be particularly important for a future revision of the Coleosporium-solidaginis-asterum complex in order to document species delimitation, host preferences, and distribution. Until then, the name "Coleosporium asterum" should only be used for specimens on Aster s.l., and "Coleosporium solidaginis" should be used for species on Solidago spp.

The Coleosporium-solidaginis-asterum complex belongs to a well-supported clade containing all species originally native to America (Fig. 1), including those (neomycete) specimens collected outside America (Table S1). Species native to Asia and Europe appear intermixed in the remaining clades. Two specimens of $C$. senecionis introduced in Australia (Walker and Priest 1984) and New Zealand (McKenzie 1998) appear in the European clade as well (Figs. 1 and 2, Table S1). The phylogenetic pattern within the genus follows the biogeographic 
distribution of the species rather than their host preferences. For example, species occurring on Asteraceae appear in different positions in the phylogenetic trees (Figs. 1 and 2). Thus, C. solidaginis and C. asterum are more closely related to species from America, which do not occur on Asteraceae, like the American C. ipomoeae on Ipomea spp. (Convolvulaceae) and C. plumeriae on Plumeria spp. (Apocynaceae) native to the Caribbean, than to Asian or European Coleosporium species on Asteraceae (Figs. 1 and 2). In conclusion, the relationship among the telial host plants is not always an indicator for the relationship within the genus Coleosporium. Therefore, we conclude that host jumps played a more important role than cospeciation in the evolution of Coleosporium species (cf. McTaggart et al. 2016). This particularly applies to the European Coleosporium species.

Most of the European species could not be distinguished in the present molecular analyses, even though they occur on different host families (Figs. 1, 2, S1, and S2). Neither the LSU nor the ITS sequences separate $C$. cacaliae, C. campanulae, C. euphrasiae, C. melampyri, C. senecionis, and $C$. sonchi from each other. These results are in contradiction to infection experiments that distinguished $C$. euphrasiae on Euphrasia and Rhinanthus spp. from C. melampyri on Melampyrum spp. (Gäumann 1959, and literature cited therein). Gäumann (1959) also split C. campanulae and C. senecionis into several formae speciales because of their preferences for specific Campanula and Senecio host species. Rusts from seven Campanula and four Senecio species were included in the present analyses, but the molecular data do not support a separation among them. In summary, the European Coleosporium spp., which occur on the distantly related families (orders) Asteraceae, Campanulaceae (both Asterales), and Orobanchaceae (Lamiales), are not distinguishable from each other using LSU and ITS sequence data. Indeed, the barcoding sequence of the ITS region cannot always discriminate among biologically well-separated species (e.g., Beenken et al. 2012; Schoch et al. 2012; Scholler et al. 2016). The morphological characteristics of these Coleosporium species are also uniform (Helfer 2013). Some authors, therefore, have questioned the species concept based mainly on telial host plant species (e.g., Gäumann 1959) and united all European species into one species, C. tussilaginis, with several host-specific formae speciales (f.sp.) (Boerema and Verhoeven 1972; Helfer 2013; Hylander et al. 1953; Majewski et al. 2008; Wilson and Henderson 1966; Index Fungorum 2017). However, the phylogenies presented in this study (Figs. 1, 2, S1, and S2) do not support this broad species concept in all cases. Four of the ten investigated European species were well separated (Figs. 1, 2, S1, and S2). Coleosporium inulae, which also differs morphologically from the other European species by the presence of a clearly thicker apical teliospore cell wall (e.g., Braun 1982), is well separated by its molecular phylogenetic position (Figs. 1, 2,
S1, and S2). The same applies to C. pulsatillae (Figs. 2 and $\mathrm{S} 1$ ). It is not resolved whether $C$. tussilaginis and $C$. petasitis are conspecific, because of the small differences in their sequences, but they are definitely not conspecific with other European species, from which they differ significantly in their ITS sequences (Figs. 2, S1, and S2). Thus, investigations of additional collections and further DNA regions with better resolution are needed to determine which European Coleosporium species are conspecific. In contrast, the Asian and American species are well separated from each other in all phylogenetic analyses (Figs. 1, 2, S1, and S2).

\section{Distribution and spread}

Coleosporium solidaginis is very common in North America and occurs on more than 50 Solidago spp. and several Pinus spp. native to this region (Arthur 1907, 1924, 1927, 1962; Farr and Rossman 2017; Ginns 1986; Hedgcock and Hunt 1922; Hunt 1926). The first reports of this rust species came from North Carolina (Schweinitz 1822), New Jersey, and New York (Thümen 1878). Outside of North America, C. solidaginis has been found only recently and often in association with introduced American Solidago species. Consequently, it can be assumed that $C$. solidaginis originated from North America (Hedgcock and Hunt 1922).

In East Asia, C. solidaginis (as C. asterum) was found in Japan on the indigenous S. virgaurea var. asiatica (Kaneko 1981 ), in South Korea on the indigenous S. virgaurea var. gigantea Nakai (Back et al. 2014), and in China, specifically in Jiangxi Province on Solidago sp. (Tai 1979), in Fujian Province on the indigenous $S$. decurrens Lour. (Zhuang 1983, 2001), and in Zhejiang Province on the introduced S. canadensis (Wang et al. 2017). In India, C. solidaginis was also found on S. canadensis (Thite et al. 2016). A finding of $C$. solidaginis on $S$. virgaurea in a pine forest in northeast Turkey is the observed occurrence located nearest to Europe (Bahcecioglu and Kabaktepe 2012; Kabaktepe 2010). These recent reports of $C$. solidaginis in Asia suggest that the rust was also recently introduced to Asia and subsequently spread throughout that region. Because the rusts on S. virgaurea var. gigantea in South Korea and on S. canadensis in China belong to different subclades (Fig. 1), at least two introduction events in Asia may be postulated.

Menéndez and Rubio (2012) ${ }^{3}$ published and illustrated the first European record online as C. asterum on S. virgaurea from northern Spain, Asturias, near Lamuño, Cudillero, at the recreation area of Monte Valsera, observed in November 2007. The first report of C. solidaginis in Germany dates back to 2009

\footnotetext{
${ }^{3}$ The record includes a photo of the infected plant and a photo of urediniospores viewed through a microscope. Therefore, we consider this a valid record and the first one from Europe, even though it was not published in a scientific journal.
} 
(Klenke and Scholler 2015). It was collected from S. gigantea by P. Dornes in Baden-Württemberg, Karlsruhe, close to the river Rhine (Table S2). Interestingly, the rust species was confirmed numerous times in the Upper Rhine Valley in Germany, but outside the valley, it could not be found, despite systematic searching. Coleosporium solidaginis was also observed on $S$. gigantea cultivated in the botanical garden of the University of Constance (Germany) in July 2016 (M. Tomowski, pers. communication). In Switzerland, the hot spot of infection of $S$. virgaurea and $S$. gigantea is in the Canton Ticino, where C. solidaginis was first found in 2012 (Brodtbeck 2017). North of the Alps, C. solidaginis seems to be scarcer and was found only in a few places close to the river Rhine and its tributary Töss in Switzerland (Table S2; Brodtbeck 2017). A continually updated distribution map for Switzerland is given by Senn-Irlet et al. (2017), and a worldwide map including the German records is located at the Global Biodiversity Information Facility (http:// www.gbif.org).

Although potential host plants (S. gigantea, $S$. virgaurea) are widely distributed (Wagenitz 1979), the sudden appearance of C. solidaginis in Europe in places far away from each other raises the question as to the pathway of its introduction. One possibility is that $C$. solidaginis was introduced with living pine trees or goldenrods directly from North America or via Asia by human activities like plant trade (Palm and Rossman 2003). Alternatively, it may have been introduced through longdistance propagation by airborne spores (Brown and Hovmøller 2002; Kolmer 2005; Viljanen-Rollinson and Cromey 2002), possibly via Asia, with native as well as introduced Solidago and Pinus species as stepping stones. The current distribution of $C$. solidaginis in Europe may be the result of a combination of both mechanisms. For comparison, several other neomycetes have reached southern Switzerland via Italy (Beenken and Senn-Irlet 2016); for example, the North American powdery mildew of the plane tree, Erysiphe platani (Howe) U. Braun \& S. Takam. (Beenken 2017) and, recently, Favolaschia calocera R. Heim (Spinelli 2016). Scholler et al. (2012) assumed that neomycetes enter Central Europe north of the Alps from the west via the Burgundian Gate (Belfort Gap). Examples of plant parasitic neomycetes that probably spread this way to Germany are the Australian Asteraceae rust Puccinia lagenophorae Cooke and the plane powdery mildew (Scholler et al. 2012). However, reports of $C$. solidaginis from the neighboring countries, such as Italy and France, are still lacking. Finally, knowledge of the distribution of $C$. solidaginis in Europe is quite limited and based mainly on accidental observations by a few rust specialists. Thus, it is difficult to determine when and where $C$. solidaginis first arrived in Europe.

\section{Host shifts}

It is widely accepted that host shifts or jumps of plant pathogenic fungi occur mainly between closely related plant species (e.g., Bufford et al. 2016). Therefore, it was not surprising that $C$. solidaginis could infect the native $S$. virgaurea. When and where the host shift from an American Solidago species to the European $S$. virgaurea has happened is still not clear. This host shift could have already occurred in North America. Hunt (1926) listed two old records of $C$. solidaginis on introduced $S$. virgaurea plants from the New England states in the USA. Additional host shifts may have occurred in Asia, where C. solidaginis was found on introduced Solidago species, as well as on $S$. virgaurea (see above), or recently in Europe. Probably, the host shift to $S$. virgaurea has happened several times in several places.

A comparable host shift — but in the opposite directionwas verified by barcoding in the present study. Coleosporium senecionis, a native rust common on native Senecio spp., jumped to the invasive neophyte Senecio inaequidens from South Africa. Whereas the plant was introduced to Europe already at the end of the nineteenth century and became invasive in the second half of the twentieth century (Heger and Böhmer 2005; Weber 2013), the rust on S. inaequidens was first reported in Europe (Germany) in 2000 (Schmitz and Werner 2001). Nowadays, C. senecionis is quite common on S. inaequidens in Central Europe (e.g., Klenke and Scholler 2015). Interestingly, the European $C$. senecionis was also introduced to Australia and New Zealand (Fig. 1), where it occurs on introduced Senecio spp., as well as on native Asteraceae (Laundon 1978; McKenzie 1998; Walker and Priest 1984).

\section{Life cycle}

All collections of $C$. solidaginis investigated for the present study showed uredinia (Fig. 3a-d). Telia with basidia and basidiospores (Fig. 3e) were only found once, on $S$. gigantea in Switzerland (LB11178/ZT-Myc-58016), even though the rust fungi were mainly collected in the late autumn when telia are typically present (Tables S2 and S3). Like all other heteroecious Coleosporium species, C. solidaginis forms spermogonia and aecia on needles of Pinus spp., subgenus Pinus (Farr and Rossman 2017; Nicholls et al. 1968). Up to now, aecia, which were reported from North America as Peridermium acicola (Hedgcock and Hunt 1922), have not been documented in Europe, although a potential host, the native two-needle pine Pinus sylvestris, was observed at all locations where $C$. solidaginis was found. Pinus sylvestris was reported to be an aecial host of $C$. solidaginis (as $C$. asterum), even in Canada (Baranyay et al. 1962; Ziller 1974). Therefore, the infection of $P$. sylvestris and the formation of spermogonia and aecia on needles would be expected in Switzerland and Germany.

Telio- and basidiospores were reported only rarely in Central Europe, and, thus, $C$. solidaginis propagation in this region apparently occurs in most cases by asexual 
Fig. 3 Coleosporium solidaginis: a flowering Solidago virgaurea, slightly infected by the rust fungus (Switzerland,

Bellinzona, 31.08.2014); b rosette leaf of $S$. virgaurea, heavily affected by uredinia (Switzerland, Stadel, 13.11.2016); c urediniospore in face view; $\mathbf{d}$ urediniospore in optical section; $\mathbf{e}$ section through telium on

$S$. gigantea, insert: basidiospore; (c-e from LB11178/ZT-Myc58016)
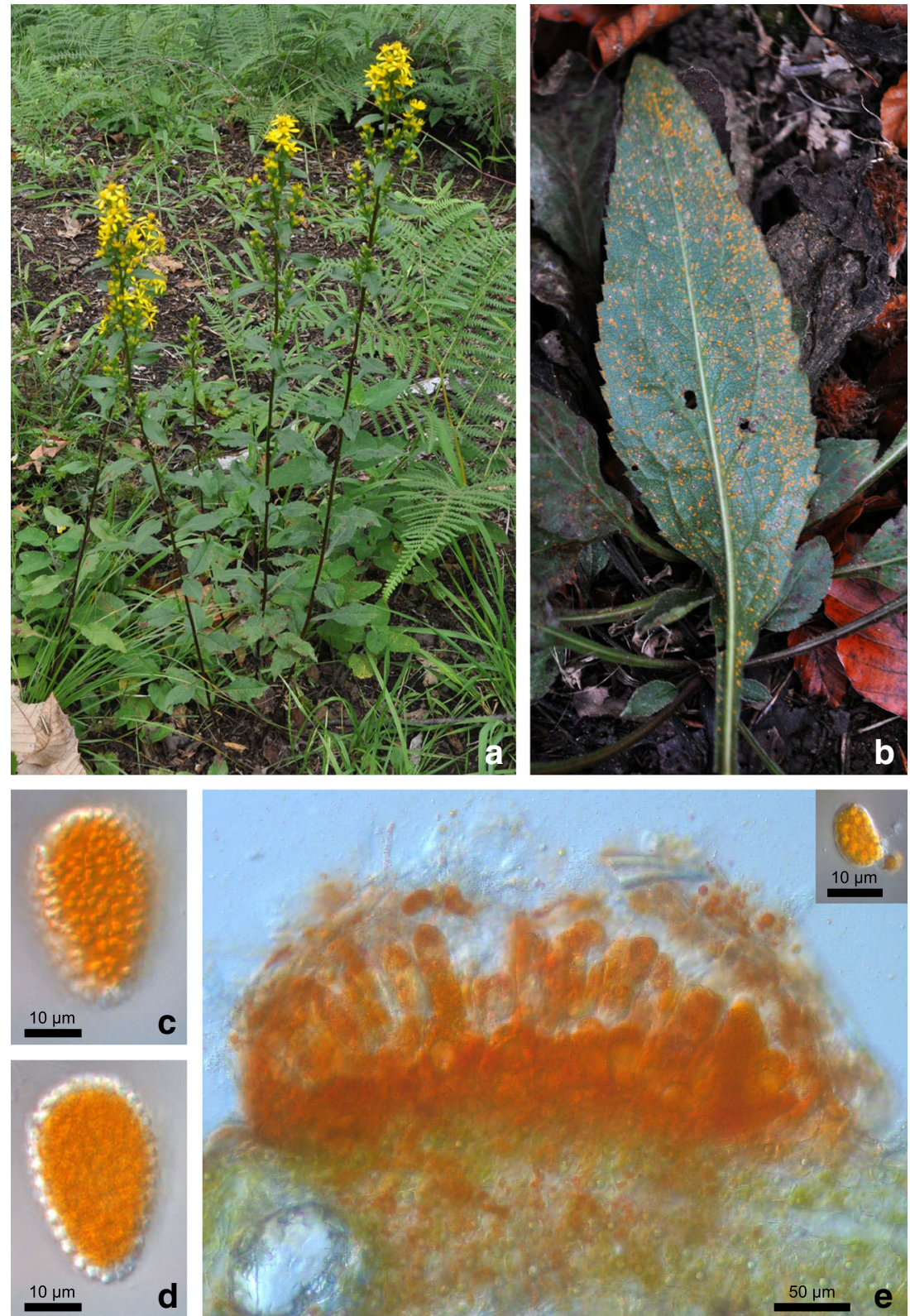

urediniospores. Observations from North America (Mains 1916; Nicholls et al. 1968) and from Asia (Back et al. 2014) have demonstrated that $C$. solidaginis can overwinter without an aecial host, as urediniospores and mycelia on green leaves of Solidago plants, in mild winter climates where leaf rosettes can survive. In contrast, in our study, all leaves of $S$. gigantea and S. virgaurea died back and dried out during winter 2016/ 17 at all sites in Switzerland (Table S3). Thus, living mycelia and urediniospores were not observed on leaves in early spring. Clinton (1908), Mains (1916), and Nicholls et al. (1968) reported that mycelia of $C$. solidaginis were not perennial in the belowground organs of Solidago plants. However, it is possible that urediniospores survived in the leaf litter and soil and reinfected young leaves in spring, which would explain why the rust occurred in several stands of Solidago spp. during five years of observations but disappeared at other locations (Table S3). Consequently, removing all infected aboveground parts of the plants in autumn may inhibit the reinfection of Solidago plants by $C$. solidaginis the next spring.

\section{Impact}

Some rust fungi are discussed as a biocontrol agent against invasive neophytes (e.g., Tanner et al. 2015). From that point of view, the reduction of the fitness of the invasive $S$. gigantea would be a positive effect of the $C$. solidaginis introduction. On the other hand, the indigenous $S$. virgaurea is potentially 
threatened by this rust fungus. However, it is currently difficult to estimate the ecological and economic impact of C. solidaginis in Europe because little is known about its distribution and velocity of propagation. In the field, slightly infected plants of S. virgaurea (Fig. 3a) and S. gigantea flowered and produced seeds, but heavily infected plants of $S$. virgaurea were found to produce only sterile leaf rosettes (Fig. 3b). However, these field observations were not quantified. The presumed reduction of the fitness of host plants and the resulting impact of the alien pathogen on their competitiveness (Frantzen and Müller-Schärer 2006) need to be validated by experiments that quantify indicators of fitness, such as seed production per plant. In South Korea, Back et al. (2014) estimated that the productivity loss of the cultivated medicinal plant $S$. virgaurea var. gigantea due to rust disease is more than $10 \%$. Similar loss rates could, therefore, be expected for cultures of $S$. virgaurea in Europe if $C$. solidaginis becomes more widespread. As a consequence, programs to control invasive Solidago species, which exist in several European countries (e.g., Weber 2013), should, as a preventive measure, emphasize areas where the native $S$. virgaurea occurs to protect it against $C$. solidaginis transmitted by nonnative goldenrods. In cultures of goldenrods, the best phytosanitary treatment is to clean fields of all infected plant material (see above).

The powdery mildew Golovinomyces asterum var. solidaginis U. Braun, which is a North American neomycete as well (Beenken and Senn-Irlet 2016; Braun and Cook 2012; Klenke and Scholler 2015), was also found on all Solidago species in the present study, often associated with C. solidaginis on the same plant (Table S3). The extent to which the damage of the plants may be enhanced by such mixed infections is unknown. Pinus sylvestris is the second potential native host of $C$. solidaginis that could be affected. In North America, Ziller (1974) observed that the damage on pine needles by the aecial stage was mostly negligible, especially on older trees, but Mihail et al. (2002) observed a significant growth reduction of trees by infection with the pine needle rust $C$. solidaginis (as $C$. asterum).

In conclusion, $C$. solidaginis is a neomycete with origin in North America that has become established in several regions of Central Europe within a relatively short period and has the potential to spread across Europe and become invasive on indigenous plants.

Acknowledgements The authors thank Beatrice Senn-Irlet and Valentin Queloz (WSL Birmensdorf) for their substantial support during the Swiss part of the study. Thomas Brodtbeck (Riehen near Basel) kindly shared locations of rust fungi in Switzerland. Jasmin Joshi (University of Potsdam) gave valuable information about neophytes in general and in particular about invasive goldenrods. Maxi Tomowski (University of Potsdam) kindly informed us about her observations of $C$. solidaginis in Constance. The authors thank Patrick Dornes, who collected and provided the first specimen from Central Europe. Many thanks go to the
Genetic Diversity Centre (GDC) of the ETH Zurich, where the sequences of Swiss specimens were generated and all molecular data were analyzed. Melissa Dawes provided linguistic suggestions on the manuscript. The Swiss Federal Office for the Environment financed the first author's (L.B.) involvement in this study (FOEN project 05.0040.PZ/O2822391). DNA barcodes were determined within the framework of the German Barcode of Life (GBOL) project, which is supported by the German Federal Ministry of Education and Research (BMBF FKZ 01LI15011 to M.S.) as research for sustainable development (FONA, http://www.fona.de).

\section{References}

Altschul SF, Gish W, Miller W, Myers EW, Lipman DJ (1990) Basic local alignment search tool. J Mol Biol 215:403-410

Arthur JC (1907) Uredinales, Coleosporiaceae, Uredinaceae, Aecidiaceae (pars). North Am Flora 7(2):83-95

Arthur JC (1924) Uredinales, additions and corrections (concluded). North Am Flora 7(9):649-668

Arthur JC (1927) Uredinales, additions and corrections. North Am Flora 7(12):797-848

Arthur JC (1962) Manual of the rusts in United States and Canada. Hafner Publishing Company, New York, 438 pp

Arthur JC, Bisby GR (1918) An annotated translation of the part of Schweinitz's two papers giving the rusts of North America. Proc Am Phil Soc 57(3):173-292

Back C-G, Nam G-Y, Lee S-Y, Jung H-Y (2014) Outbreak of rust caused by Coleosporium asterum on Solidago virgaurea var. gigantea in Ulleung-do. Mycobiology 42(1):79-81

Bahcecioglu Z, Kabaktepe S (2012) Checklist of rust fungi in Turkey. Mycotaxon 119:494. http://www.mycotaxon.com/resources/ checklists/Bahcecioglu-v119-checklist.pdf

Baranyay JA, Bourchier RJ, Stevenson GR (1962) Province of Alberta. Forest disease conditions. In: Annual report of the forest insect and disease survey 1962. Can Dep Forest, Ottawa, pp 99-105

Beenken L (2017) First records of the powdery mildews Erysiphe platani and E. alphitoides on Ailanthus altissima reveal host jumps independent of host phylogeny. Mycol Prog 16:135-143

Beenken L, Senn-Irlet B (2016) Neomyceten in der Schweiz, Stand des Wissens und Abschätzung des Schadpotentials der mit Pflanzen assoziierten gebietsfremden Pilze. WSL Berichte 50, pp 1-93. https://www.dora.lib4ri.ch/wsl/islandora/object/wsl:9106

Beenken L, Zoller S, Berndt R (2012) Rust fungi on Annonaceae II: the genus Dasyspora Berk. \& M.A. Curtis. Mycologia 104:659-681

Boerema GH, Verhoeven AA (1972) Check-list for scientific names of common parasitic fungi. Series 1a: Fungi on trees and shrubs. Neth J Plant Pathol 78(Suppl 1):1-55

Braun U (1982) Die Rostpilze (Uredinales) der Deutschen Demokratischen Republik. Feddes Repert 93:213-333

Braun U, Cook RTA (2012) Taxonomic manual of the Erysiphales (powdery mildews), CBS Biodiversity Series, vol 11. CBS, Utrecht

Brodtbeck T (2017) Coleosporium asterum (Dietel) Syd. \& P. Syd. (Pucciniales, Pucciniomycota), pp 135-138. In: Kruse J et al. Bemerkenswerte Funde phytoparasitischer Pilze (7). Z Mykol 83(1):127-156

Brown JKM, Hovmøller MS (2002) Aerial dispersal of pathogens on the global and continental scales and its impact on plant disease. Science 297:537-541

Bufford JL, Hulme PE, Sikes BA, Cooper JA, Johnston PR, Duncan RP (2016) Taxonomic similarity, more than contact opportunity, explains novel plant-pathogen associations between native and alien taxa. New Phytol 212:657-667. https://doi.org/10.1111/nph.14077 
Castresana J (2000) Selection of conserved blocks from multiple alignments for their use in phylogenetic analysis. Mol Biol Evol 17:540 552

Clinton GP (1908) Report of the botanist for 1907 III. Heteroecious rusts of Connecticut having a Peridermium for their aecial stage. Rep Connecticut Agric Exp Sta: 368-396, plates XXV-XXXII

Cummins GB (1962) Supplement to Arthur's manual of the rusts in United States and Canada. In: Arthur JC (ed) Manual of the rusts in United States and Canada. Hafner Publishing Company, New York, pp 1A-24A

Cummins GB (1978) Rust fungi on legumes and composites in North America. University of Arizona Press, Tucson

Dietel P (1900) Uredineae japonicae I. Botanische Jahrbücher für Systematik, Pflanzengeschichte und Pflanzengeographie. Bot Jahrb Syst 27:564-576, plate VIII

Farr DF, Rossman AY (2017) Fungal databases, systematic mycology and microbiology laboratory, ARS, USDA. Retrieved 15 May 2017, from https://nt.ars-grin.gov/fungaldatabases/ fungushost/fungushost.cfm

Frantzen J, Müller-Schärer H (2006) Modeling the impact of a biocontrol agent, Puccinia lagenophorae, on interactions between a crop, Daucus carota, and a weed, Senecio vulgaris. Biol Control 37: 301-306

Gäumann E (1959) Die Rostpilze Mitteleuropas mit besonderer Berücksichtigung der Schweiz. Beitr Kryptogamenflora Schweiz 12:1-1407

Geiger MF, Astrin JJ, Borsch T, Burkhardt U, Grobe P, Hand R, Hausmann A, Hohberg K, Krogmann L, Lutz M, Monje C, Misof B, Morinière J, Müller K, Pietsch S, Quandt D, Rulik B, Scholler M, Traunspurger W, Haszprunar G, Wägele W (2016) How to tackle the molecular species inventory for an industrialized nation-lessons from the first phase of the German Barcode of Life initiative GBOL (2012-2015). Genome 59(9):661-670

Ginns JH (1986) Compendium of plant disease and decay fungi in Canada 1960-1980. Res Br Can Agric Publ 1813:1-416

Gudžinskas Z, Žalneravičius E (2016) Solidago $\times$ snarskisii nothosp. nov. (Asteraceae) from Lithuania and its position in the infrageneric classification of the genus. Phytotaxa 253(2):147-155

Hantula J, Scholler M (2013) NOBANIS - invasive alien species fact sheet-Melampsoridium hiratsukanum. From: online database of the European Network on Invasive Alien Species-NOBANIS. https://www.nobanis.org/fact-sheets/. Accessed 15 May 2017

Heath MC (1992) Host species specificity of the goldenrod rust fungus and the existence of rust resistance within some goldenrod species. Can J Bot 70:2461-2466

Hedgcock GG, Hunt NR (1922) Notes on some species of Coleosporium: II. Mycologia 14(6):297-310

Heger T, Böhmer HJ (2005) The invasion of Central Europe by Senecio inaequidens DC. Erdkunde 59:34-49

Helfer S (2013) Coleosporium in Europe. Mycotaxon 124:87-99

Hennen JF, Figueiredo MB, de Carvalho AA Jr, Hennen PG (2005) Catalogue of the species of plant rust fungi (Uredinales) of Brazil. Jardim Botanico do Rio de Janeiro, Rio de Janeiro. https:// aplicacoes.jbrj.gov.br/publica/livros_pdf/catalogue.pdf

Hunt WR (1926) The Uredinales or rusts of Connecticut and the other New England states. Connecticut State Geol Surv Bull 36:1-198

Huson DH, Richter DC, Rausch C, Dezulian T, Franz M, Rupp R (2007) Dendroscope: an interactive viewer for large phylogenetic trees. BMC Bioinformatics 8:460

Hylander N, Jørstad I, Nannfeldt JA (1953) Enumeratio uredinearum Scandinavicarum. Opera Bot 1:1-102

Index Fungorum (2017) http://www.indexfungorum.org. Accessed January 2017

Kabaktepe S (2010) Kars ve Ardahan Yoresi vaskuler bitkiler uzerinde tespit edilen mikrofunguslar. Inonu Universitesi Fen Bilimleri Enstitusu. Phd thesis, Malatya
Kaneko S (1981) The species of Coleosporium, the causes of pine needle rusts, in the Japanese Archipelago. Rep Tollori Mycol lnst 19:1-159

Katoh K, Standley DM (2013) MAFFT multiple sequence alignment software version 7: improvements in performance and usability. Mol Biol Evol 30(4):772-780. https://doi.org/10.1093/molbev/ mst010

Katoh K, Misawa K, Kuma K, Miyata T (2002) MAFFT: a novel method for rapid multiple sequence alignment based on fast Fourier transform. Nucleic Acids Res 30:3059-3066

Kirk PM, Cannon PF, Minter DW, Stalpers JA (2008) Ainsworth \& Bisby's dictionary of the fungi, 10th edn. CAB International, Wallingford

Klebahn H (1914) Kulturversuche mit Rostpilzen XV. Z Pflanzenkrankh 24:1-32

Klenke F, Scholler M (2015) Pflanzenparasitische Kleinpilze. Springer, Berlin

Kolmer JA (2005) Tracking wheat rust on a continental scale. Curr Opin Plant Biol 8:441-449

Kołodziej B (2009) Optimalisation of mineral fertilization in goldenrod (Solidago virgaurea L. ssp. virgaurea) cultivated for pharmaceutical purposes. Acta Sci Pol Hortorum Cultus 8(1):27-36

Kowarik I, Rabitsch W (2010) Biologische Invasionen: Neophyten und Neozoen in Mitteleuropa. Eugen Ulmer, Stuttgart

Kreisel H, Scholler M (1994) Chronology of phytoparasitic fungi introduced to Germany and adjacent countries. Bot Acta 107:387-392

Large E (2003) The advance of the fungi. APS Press, St. Paul, MN

Laundon GF (1978) A Coleosporium rust new to New Zealand. Plant Dis Rep 62(9):796-797

Maier W, Begerow D, Weiß M, Oberwinkler F (2003) Phylogeny of the rust fungi: an approach using nuclear large subunit ribosomal DNA sequences. Can J Bot 81:12-23

Mains EB (1916) The wintering of Coleosporium solidaginis. Phytopathology 6:371-372

Majewski T, Ruszkiewicz-Michalska M (2008) Uredinales. In: Mulenko $\mathrm{W}$ et al (eds) A preliminary checklist of micromycetes in Poland. W. Szafer Institute of Botany, Krakow, pp 263-297

McKenzie EHC (1998) Rust fungi of New Zealand - an introduction, and list of recorded species. N Z J Bot 36(2):233-271

McNeill J, Barrie FR, Burdet HM, Demoulin V, Hawksworth DJ, Marhold K, Nicolson DH, Prado J, Silva PC, Skog JE, Wiersema JH, Turland NJ (2006) International Code of Botanical Nomenclature (Vienna Code). Regnum Vegetabile 146(i-Xviii):1568

McNeill J, Barrie FR, Buck WR, Demoulin V, Greuter W, Hawksworth DL, Herendeen PS, Knapp S, Marhold K, Prado J, Prud'homme Van Reine WF, Smith GF, Wiersema JH, Turland NJ (2012) International Code of Nomenclature for algae, fungi and plants (Melbourne Code) adopted by the Eighteenth International Botanical Congress Melbourne, Australia, July 2011. Koeltz Scientific Books, Regnum Vegetabile 154: i-xxx, 1-208. http://www.iapt-taxon.org/ nomen/main.php

McTaggart AR, Shivas RG, van der Nest MA, Roux J, Wingfield BD, Wingfield MJ (2016) Host jumps shaped the diversity of extant rust fungi (Pucciniales). New Phytol 209:1149-1158

Menéndez JL, Rubio E (2012) https://www.asturnatura.com/fotografia/ setas-hongos/coleosporium-asterum-dietel-syd-p-syd-1/13863. html. Accessed 7 Feb 2017

Mihail JD, Bruhn JN, Meyer TR, Bell FW (2002) Pine needle rust effect on Pinus banskiana in response to interspecific plant competition and telial host density. Can J For Res 32(8):1372-1380

Nehring S, Kowarik I, Rabitsch W, Essl F (eds) (2013) Naturschutzfachliche Invasivitätsbewertungen für in Deutschland wild lebende gebietsfremde Gefäßpflanzen. BfN-Skripten 352:1202 
Nicholls TH, Patton RF, Van Arsdel EP (1968) Life cycle and seasonal development of Coleosporium pine needle rust in Wisconsin. Phytopathology 58:822-829

Palm ME, Rossman AY (2003) Invasion pathways of terrestrial plantinhabiting fungi. In: Ruiz GM, Carleton JT (eds) Invasive species: vectors and management strategies. Island Press, Washington, DC, pp 31-43

Pfunder M, Schürch S, Roy BA (2001) Sequence variation and geographic distribution of pseudoflower-forming rust fungi (Uromyces pisi $\mathrm{s}$. lat.) on Euphorbia cyparissias. Mycol Res 105:57-66

Pliszko A, Zalewska-Gałosz J (2016) Molecular evidence for hybridization between invasive Solidago canadensis and native S. virgaurea. Biol Invasions 18:3103-3108

Santini A, Ghelardini L, De Pace C, Desprez-Loustau ML, Capretti P, Chandelier A, Cech T, Chira D, Diamandis S, Gaitniekis T, Hantula J, Holdenrieder O, Jankovsky L, Jung T, Jurc D, Kirisits T, Kunca A, Lygis V, Malecka M, Marcais B, Schmitz S, Schumacher J, Solheim H, Solla A, Szabò I, Tsopelas P, Vannini A, Vettraino AM, Webber J, Woodward S, Stenlid J (2013) Biogeographical patterns and determinants of invasion by forest pathogens in Europe. New Phytol 197: 238-250

Schenk R, Lück L (2012) Goldrute, Echte (Solidago virgaurea L.), pp. 488-500. In: Hoppe B (ed) Handbuch des Arznei- und Gewürzpflanzenbaus. Band 4. Verein für Arznei- und Gewürzpflanzen Saluplanta e.V., Bernburg, Germany

Schmitz G, Werner DJ (2001) The importance of the alien plant Senecio inaequidens DC. (Asteraceae) for phytophagous insects. Z Ökol Nat 9(3):153-160

Schoch CL, Seifert KA, Huhndorf S, Robert V, Spouge JL, Levesque CA, Chen W; Fungal Barcoding Consortium (2012) Nuclear ribosomal internal transcribed spacer (ITS) region as a universal DNA barcode marker for fungi. Proc Nat Acad Sci U S A 109:6241-6246

Scholler M, Hemm V, Lutz M (2012) Erysiphe platani: monitoring of an epidemic spread in Germany and molecular characterization based on rDNA sequence data. Andrias 19:263-272

Scholler M, Schmidt A, Siahaan SAS, Takamatsu S, Braun U (2016) A taxonomic and phylogenetic study of the Golovinomyces biocellatus complex (Erysiphales, Ascomycota) using asexual state morphology and rDNA sequence data. Mycol Prog 15:56. https://doi.org/10. 1007/s11557-016-1197-5

Schweinitz LD (1822) Synopsis fungorum Carolinae superioris. Schr Naturf Ges Leipzig 1:20-131

Senn-Irlet BJ, Gross A, Blaser S (2017) SwissFungi: national data- and information center for the fungi of Switzerland (database). Version 2. Birmensdorf, Swiss Federal Institute WSL. http://www. swissfungi.ch. Accessed 24 Jan 2017

Shivas R, Beasley D, McTaggart A (2017) Rust Fungi of Australia. http:// collections.daff.qld.gov.au/web/key/rustfungi/Media/Html/index. $\mathrm{html}$

Sieber TN (2014) Neomyzeten — eine anhaltende Bedrohung für den Schweizer Wald. Schweiz Z Forstwes 165(6):173-182
Spinelli C (2016) Favolaschia calocera, un fungo tropici in marcia verso nord, ora anche Ticino. SZP/BSM 3:13-15

Stamatakis A (2006) RAxML-VI-HPC: maximum likelihood-based phylogenetic analyses with thousands of taxa and mixed models. Bioinformatics 22:2688-2690

Stamatakis A, Hoover P, Rougemont J (2008) A rapid bootstrap algorithm for the RAxML Web servers. Syst Biol 57:758-771

Sydow H, Sydow P (1914) Beitrag zur Kenntnis der parasitischen Pilze der Insel Formosa. Ann Mycol 12(2):105-112

Tai FL (1979) Sylloge Fungorum Sinicorum. Science Press, Academia Sinica, Peking

Tanner RA, Pollard KM, Varia S, Evans HC, Ellison CA (2015) First release of a fungal classical biocontrol agent against an invasive alien weed in Europe: biology of the rust, Puccinia komarovii var. glanduliferae. Plant Pathol 64:1130-1139

Thite SV, Hande PR, Kore BA (2016) Occurrence of rust on Solidago canadensis, a new host record for Coleosporium asterum from India. Plant Pathol Quarant 6(1):43-46

Thümen F (1878) New species of North American Uredinei. Bull Torrey Bot Club 6(39):215-216

Van Reenen M (1995) An annotated list of Urediniomycetes (rust fungi) from South Africa 1: Melampsoraceae and Pucciniaceae, excluding Puccinia and Uromyces. Bothalia 25(2):173-181

Vilgalys R, Hester M (1990) Rapid genetic identification and mapping of enzymatically amplified ribosomal DNA from several Cryptococcus species. J Bacteriol 172(8):4238-4246

Viljanen-Rollinson SLH, Cromey MG (2002) Pathways of entry and spread of rust pathogens: implications for New Zealand's biosecurity. N Z Plant Prot 55:42-48

Vogel A (2017) http://www.avogel.ch/de/pflanzenlexikon/solidago_ virgaurea.php. Accessed 7 Feb 2017

Wagenitz G (1979) Solidago L. In: Hegi G (ed) Illustrierte Flora von Mitteleuropa, 6 (3). Carl Hanser, München, pp 16-29

Walker J, Priest MJ (1984) Coleosporium senecionis in Australia. New South Wales Department of Agriculture, Plant Disease Survey 1982-83, pp 28-29

Wang Q, Li X-L, Zhang J-Z (2017) First report of goldenrod rust caused by Coleosporium asterum in China. Plant Dis 101(2):389-389

Weber E (2013) Invasive Pflanzen der Schweiz. Haupt, Bern

Weber E, Jakobs G (2005) Biological flora of central Europe: Solidago gigantea Aiton. Flora 200:109-118

Wilson M, Henderson DM (1966) British rust fungi. Cambridge University Press, Cambridge

Zhuang J-Y (1983) A provisional list of Uredinales of Fujian Province, China. Acta Mycol Sin 2(3):146-158

Zhuang W-Y (2001) Higher fungi of tropical China. Mycotaxon Ltd., Ithaca, New York

Ziller WG (1974) The tree rusts of western Canada. Pacific Forest Research Centre, Victoria, BC. Publication 1329, 272 pp 